\title{
Monthly Variations in Fresh Semen Parameters of Surti Buck in Rainy Season
}

\author{
D. K. Patel", C. F. Chaudhari, N. F. Chaudhari, L. C. Modi, V. B. Atara, \\ P. P. Panchal and Amarjeet
}

Department of Veterinary Gynaecology and Obstetrics, College of Veterinary Science and Animal Husbandry, Navsari Agricultural University, Navsari, Gujarat, India

\author{
*Corresponding author
}

\begin{tabular}{|c|c|}
\hline & A B S T R A C T \\
\hline Keywords & \multirow{4}{*}{$\begin{array}{l}\text { Ninety six semen ejaculates from eight Surti bucks were collected and } \\
\text { examined for various fresh semen parameters during rainy season. Weekly } \\
\text { one ejaculate was collected from each buck up to } 12 \text { weeks from July to } \\
\text { September months. All the ejaculates were divided and compared month- } \\
\text { wise viz., July }(\mathrm{n}=32) \text {; August }(\mathrm{n}=40) \text { and September }(\mathrm{n}=24) \text { months. All } \\
\text { the fresh semen parameters viz., semen volume, density, mass activity, } \\
\text { sperm concentration and total sperm count were non-significantly differed } \\
\text { between individual bucks. The average semen volume, density and mass } \\
\text { activity differed non-significantly between three months. While, the sperm } \\
\text { concentration and total sperm count were significantly }(\mathrm{P}<0.01) \text { increased } \\
\text { from early rainy season towards the end of the season. }\end{array}$} \\
\hline $\begin{array}{l}\text { Buck semen, Fresh } \\
\text { semen parameters, } \\
\text { Rainy season, Surti } \\
\text { buck }\end{array}$ & \\
\hline Article Info & \\
\hline $\begin{array}{l}\text { Accepted: } \\
12 \text { November } 2020 \\
\text { Available Online: } \\
10 \text { December } 2020 \\
\end{array}$ & \\
\hline
\end{tabular}

\section{Introduction}

Goat husbandry practice is gaining importance as an alternate food source. Population of goat in India showing an increase of $10.14 \%$ from 135.17 million in 2012 to 148.88 million in 2019.Goats play an important role in the food and nutritional security of the rural poor especially in the rainfed regions where crop production is uncertain, and rearing large ruminants is restricted by acute scarcity of feed and fodder (Kumar et al., 2010). Artificial insemination (AI) has been most popular in veterinary practices and has been universally accepted for the genetic improvement of the animals (Chaudhari et al., 2007). The AI technique plays very crucial role in goat breeding to improve milk production potential of future progeny. The success of AI is chiefly depending upon semen quantitative and qualitative parameters.

Goat is a seasonal breeder animal and semen parameters in buck are influenced by age (Atara et al., 2018), scrotal circumference (Kadam et al., 2020), season (Leboeuf et al., 2000; Atara et al., 2019) and body weight 
(Zinat Mahal et al., 2013). Surti goat is a medium sized dual purpose breed and mostly confined to small towns and cities situated on the western coastal belt of the South Gujarat and mostly reared under the semi-intensive management system. Various climatic parameters viz., temperature, relative humidity, temperature humidity index, sunshine period and rainfall were significantly fluctuated between rainy and dry seasons in South Gujarat (Atara, 2017).

As the Surti goat is reared under humid heavy rainfall area in South Gujarat and the seasonality affects on semen thereby limiting the application of AI on large scale in goat, the present investigation was conducted to study monthly variation in fresh semen parameters in Surti goat particularly in rainy season.

\section{Materials and Methods}

In present experiment, total eight apparently healthy Surti male bucks above 1 $1 \frac{1}{2}$ years of age maintained under All India Coordinated Research Project (AICRP) on Goat at Livestock Research Station, Navsari Agricultural University, Navsari were selected. The selected bucks were managed under uniform managemental and feeding conditions. They were housed in a common covered pen separated from females under naturally existing photoperiod and air temperature of the South Gujarat. The bucks were trained to donate the semen in artificial vagina using male as dummy for entire June month.

After completion of the training period, semen was collected regularly by artificial vagina once in a week from each buck up to 12 weeks during rainy season from July to September months. Before semen collection, one false mount was given to the bucks on male dummy secured in trevis. During entire experiment, total ninety six semen ejaculates were collected and examined for fresh semen parameters viz., semen volume, density, mass activity, sperm concentration and total sperm count. Month-wise, all the ejaculates were divided and fresh semen parameters were compared between July $(n=32)$; August $(n=40)$ and September $(n=24)$ months.

The data pertaining to fresh semen parameters were suitably tabulated and analyzed using Statistical Package for Social Science (SPSS, Version 20). The means of different parameters were compared using Analysis of Variance, Duncan's multiple range test and presented as mean + standard error.

\section{Results and Discussion}

Individual buck-wise fresh semen parameters are summarized in table 1. All the fresh semen parameters were non-significantly differed between all the bucks. Similar to present findings, Sultana et al., (2013) also noticed non-significant difference in sperm concentration among the bucks. However, the semen volume differed significantly among the bucks in their experiment. Khadse et al., (2019) studied the buck-wise semen parameters from Sirohi goat semen. They observed comparatively higher average semen volume and comparatively lower average mean sperm concentration then the present study.

Month-wise semen parameters viz., semen volume, density, mass activity, sperm concentration and total sperm count are depicted in fig. 1 to 5 . The average semen volume (ml) of Surti buck was nonsignificantly differed between July (0.60 \pm $0.03)$, August $(0.63 \pm 0.02)$ and September $(0.58 \pm 0.03)$ months in present study (Fig. 1). Similarly, Dias et al., (2017) also found nonsignificant difference in semen volume during July, August and September months in Alpine 
bucks. While, Farshad et al., (2012) reported non-significant difference between July and August months; and significant difference in September month in Markhoz buck. Moreover, Zamiri and Heidari (2006) observed increasing trend in semen volume from July to September months. Catunda et al.(2011) reported non-significant difference between two seasons. While, Atara et al., (2019) reported significant difference in semen volume between two seasons. However, contrary to present findings, Ahmad and Noakes (1996) observed significant difference in semen volume between July, August and September months in British buck.
In present study, the mean density differed non-significantly between July (4.00 \pm 0.00$)$, August (4.00 \pm 0.00$)$ and September (3.96 \pm 0.04$)$ months (Fig. 2). Similar trend was noticed by Farshad et al., (2012) and Dias et al., (2017). They also found nonsignificant difference in sperm density between July, August and September months in their experiments. While, Zamiri and Heidari (2006) found decreased sperm density from July to September months which was in accordance with present study. Atara et al., (2019) also reported non-significant difference in semen density between two seasons.

Table.1 Individual buck-wise fresh semen parameters (Mean \pm SE) in Surti bucks

\begin{tabular}{|c|c|c|c|c|c|c|c|c|}
\hline $\begin{array}{l}\text { Sr. } \\
\text { No. }\end{array}$ & $\begin{array}{c}\text { Buck } \\
\text { No. }\end{array}$ & $\mathbf{N}$ & $\begin{array}{l}\text { Volume } \\
\text { (ml) }\end{array}$ & Density & $\begin{array}{c}\text { Mass } \\
\text { activity }\end{array}$ & $\begin{array}{l}\text { Concentration } \\
\left(\times 10^{6} / \mathrm{ml}\right)\end{array}$ & \multicolumn{2}{|c|}{$\begin{array}{l}\text { Total sperm } \\
\text { count }\left(\times 10^{6}\right)\end{array}$} \\
\hline 1 & 1201 & 12 & $0.57 \pm 0.02$ & $4.00 \pm 0.00$ & $4.92 \pm 0.08$ & $3266.67 \pm 151.27$ & \multicolumn{2}{|c|}{$1840.63 \pm 87.79$} \\
\hline 2 & 1439 & 12 & $0.58 \pm 0.03$ & $4.00 \pm 0.00$ & $4.83 \pm 0.11$ & $3143.75 \pm 162.17$ & \multicolumn{2}{|c|}{$1834.17 \pm 147.35$} \\
\hline 3 & 1517 & 12 & $0.63 \pm 0.04$ & $4.00 \pm 0.00$ & $4.75 \pm 0.13$ & $3062.50 \pm 176.28$ & \multicolumn{2}{|c|}{$1867.50 \pm 109.68$} \\
\hline 4 & 2520 & 12 & $0.67 \pm 0.06$ & $4.00 \pm 0.00$ & $4.92 \pm 0.08$ & $3081.25 \pm 141.46$ & \multicolumn{2}{|c|}{$2001.67 \pm 142.56$} \\
\hline 5 & 2546 & 12 & $0.63 \pm 0.05$ & $4.00 \pm 0.00$ & $4.75 \pm 0.13$ & $3052.08 \pm 91.52$ & \multicolumn{2}{|c|}{$1946.04 \pm 186.91$} \\
\hline 6 & 2547 & 12 & $0.64 \pm 0.05$ & $3.92 \pm 0.08$ & $4.83 \pm 0.11$ & $3002.08 \pm 164.55$ & \multicolumn{2}{|c|}{$1873.33 \pm 115.27$} \\
\hline 7 & 2655 & 12 & $0.58 \pm 0.02$ & $4.00 \pm 0.00$ & $4.92 \pm 0.08$ & $3193.75 \pm 124.44$ & \multicolumn{2}{|c|}{$1849.38 \pm 117.25$} \\
\hline 8 & 2995 & 12 & $0.58 \pm 0.03$ & $4.00 \pm 0.00$ & $4.83 \pm 0.11$ & $3252.08 \pm 161.51$ & \multicolumn{2}{|c|}{$1884.58 \pm 118.09$} \\
\hline \multicolumn{2}{|c|}{ Overall } & 96 & $0.61 \pm 0.01$ & $3.99 \pm 0.01$ & $4.84 \pm 0.04$ & $3131.77 \pm 51.52$ & & $6 \pm 44.99$ \\
\hline & $\mathrm{F}$ value & $0.84^{\mathrm{NS}}$ & $1.00^{\mathrm{NS}}$ & $0.42^{\mathrm{NS}}$ & & & & \\
\hline & $\mathrm{P}$ value & 0.56 & 0.44 & 0.89 & & & & \\
\hline
\end{tabular}

NS: Non-significant

Fig.1 Month-wise semen volume (Mean \pm SE) in Surti bucks

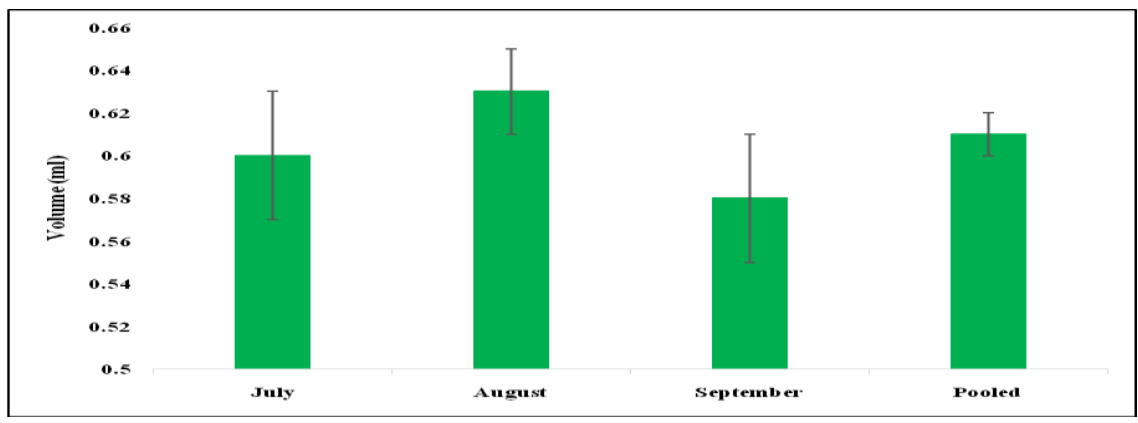


Fig.2 Month-wise semen density (Mean \pm SE) in Surti bucks

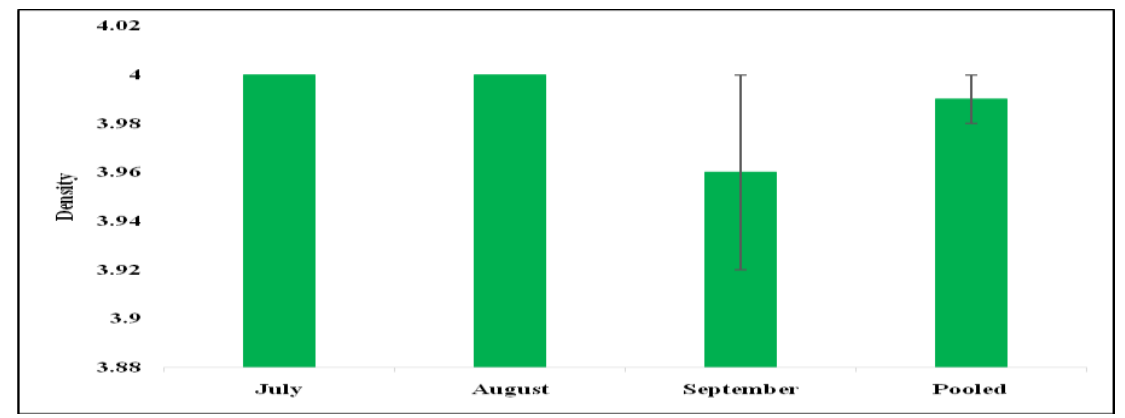

Fig.3 Month-wise semen mass activity (Mean \pm SE) in Surti bucks

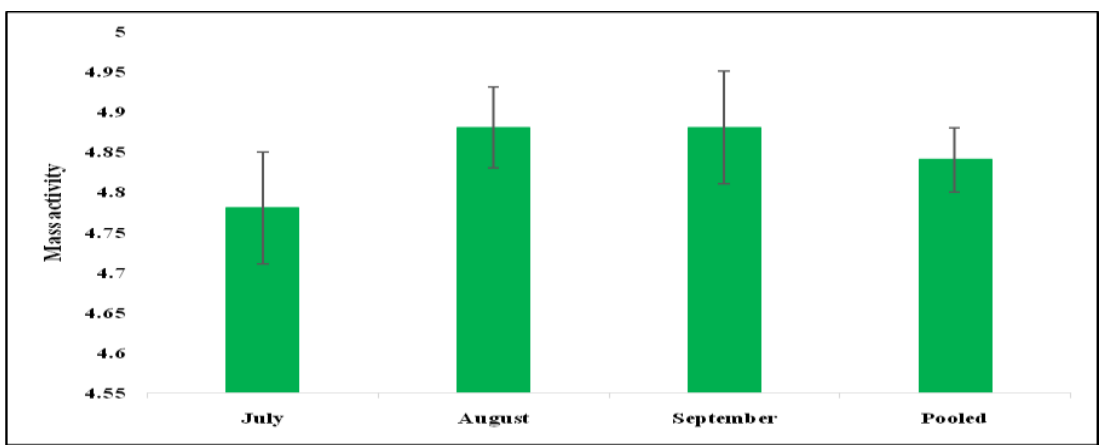

Fig.4 Month-wise sperm concentration (Mean \pm SE) in Surti bucks

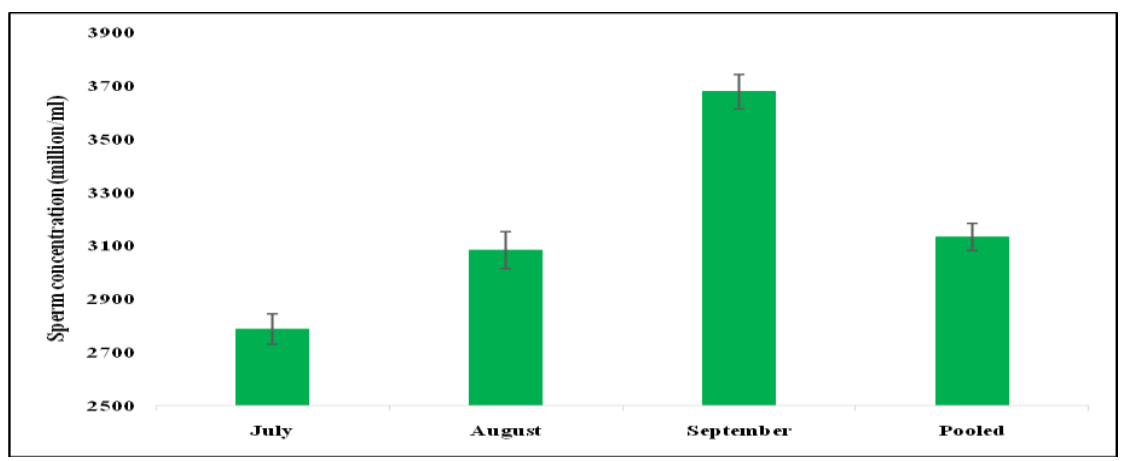

Fig.5 Month-wise total sperm count (Mean \pm SE) in Surti bucks

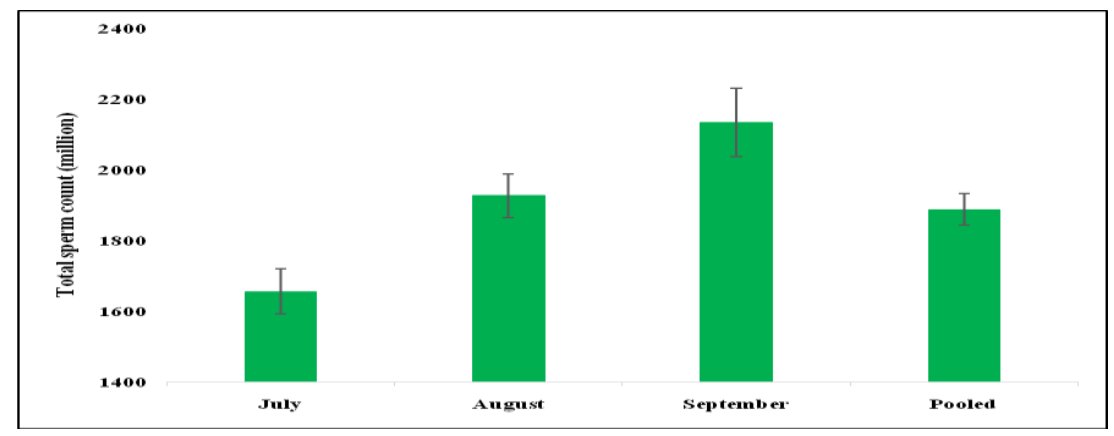


The mass activity differed non-significantly between July (4.78 \pm 0.07), August $(4.88 \pm 0.05)$ and September $(4.88 \pm 0.07)$ months in present study (Fig. 3). Similarly, Dias et al., (2017) also found non-significant difference in mass activity during July, August and September months in Alpine bucks. Atara et al., (2019) also reported nonsignificant difference in mass activity between two seasons. In concurrence to present findings of gradual increase in mass activity, Ahmad and Noakes (1996) also reported gradually increased mass motility from July, August to September months.

The sperm concentration was significantly $(\mathrm{P}<0.01)$ increased from early rainy season towards the end of the season in present experiment. It was significantly $(\mathrm{P}<0.01)$ increased from July $(2785.94 \pm 56.52$ million/ml), August $\quad(3081.88 \pm 70.08$ million $/ \mathrm{ml}$ ) to September (3676.04 \pm 65.13 million/ml) months (Fig. 4). In accordance with the present findings, Dias et al., (2017) also observed gradual increased in sperm concentration from July to September months in Alpine bucks. However, the difference between them was non-significant. While, Ahmad and Noakes (1996) reported totally reverse trend with gradually decreased sperm concentration from July, August to September months. While, Atara et al., (2019) reported non-significant difference in sperm concentration between two seasons.

Similar trend like sperm concentration was also noticed in total sperm count. It was significantly $(\mathrm{P}<0.01)$ increased from July (1654.84 \pm 63.77 million), August (1926.06 \pm 62.26 million) to September (2132.08 \pm 96.59 million) months in present study (Fig. 5).

Ahmad and Noakes (1996) and Farshad et al., (2012) also found gradually increased total sperm count from July, August to September months. Atara et al., (2019) also reported significant difference in total sperm count between two seasons. While, Zamiri and Heidari (2006) observed inconsistency in total sperm count between July to September months.

Based on the above findings it was concluded that months of the season influenced significantly on some important quantitative semen parameters viz., sperm concentration and total sperm count in Surti buck as they were improved with progression of rainy season in present experiment; breeding practices could be managed accordingly to augment reproductive efficiency of breeding bucks.

\section{Acknowledgement}

The authors are highly thankful to the ICARAICRP on goat improvement (Surti field unit), staff of LRS and Department of Animal Reproduction, Gynaecology and Obstetrics; Veterinary collage, NAU, Navsari for providing necessary help for the study.

\section{References}

Ahmad, N. and Noakes, D. E. 1996. Seasonal variations in the semen quality of young British goats. British Veterinary Journal, 152(2): 225-236.

Atara, V.B. 2017. Sexual behaviour and semen characteristics in Surti bucks. M.V.Sc. Thesis submitted to Navsari Agricultural University, Navsari.

Atara, V.B., Chaudhari, C.F., Ramani, U.V., Chaudhary, M.M., Patel, D.K., Patel, Y.R. and Patel, N.G. 2018. Semen characteristics in young and adult Surti buck. Indian J. Anim. Health, 57(2): 219-224.

Atara, V.B., Chaudhari, C.F., Tyagi, K.K., Chaudhary, M.M., Kharadi, V.B. and Dabas, V.S. 2019. Attributes of Surti buck semen in rainy and dry seasons. Indian Journal of Small Ruminants, 25 
(1): 115-117.

Catunda, A.G.V., Aguiar, G.V., Lima, I.C.S., Pereira, J.F., Pitombeira, R.S.S., Andrade, I.R.A., Martins, G.A., Souza, C.E.A., Nunes, J.F., Moura, A.A.N. and Campos, A.C.N. 2011. Characterization of ejaculates from crossbreed male goats raised in tropical environment. Revista Portuguesa Ciencias Veterinarias, 106(577-580): 59-67.

Chaudhari, C.F., Prajapati, K.R., Fatteh, A.Y. and Sipai, R.S. 2007. Semen quantitative traits in relation to the age, body weight and scrotal circumference in crossbred bulls. The Indian Journal of Field Veterinarians. 2 (4): $58-61$.

Dias, J.C.O., Veloso, C.M., Santos, M.C.D.R., Oliveira, C.T.S.A.M., Silveira, C.O., Iglesias, E. and Sanglard, L.M.P. 2017. Seasonal variation in the reproductive activity of male goats raised under tropical climate conditions. Revista Brasileira de Zootecnia, 46 (3): 192-201.

Farshad, A., Yousefi, A., Moghaddam, A. and Khalili, B. 2012. Seasonal changes in serum testosterone, LDH concentration and semen characteristics in Markhoz goats. Asian-Australian Journal of Animal Science, 25(2): 189-193.

Kadam, P.D., Raut, M.R., Sontakke, S.H. and Khadase, J.R. 2020. A study of age, body weight and scrotal circumference on semen production in buck. Int. J.
Curr. Microbiol. App. Sci. 9 (6): 12841288.

Khadse, J.R., Potdar, V.V., Sontakke, S.H., Kadam, H.D., Joshi, S.A., Swaminathan, M. and Pande, A.B. 2019. Evaluation and Freezing of Sirohi Goat Semen, Int. J. Pure App. Biosci. 7(3): 419-422.

Kumar, S., Rama Rao, C.A., Kareemulla, K. and Venkateswarlu, B. 2010. Role of goats in livelihood security of rural poor in the less favoured environments. Indian Journal of Agricultural Economics,65(4): 760781.

Leboeuf, B., Restall, B. and Salamon, S. 2000. Production and storage of goat semen for artificial insemination. Animal Reproduction Science, 62:113141.

Sultana, F., Husain, S.S., Khatun, A., Apu, A.S. and Khandoker, M.A.M.Y. 2013. Study on buck evaluation based on semen quality and fertility. Bang. J. Anim. Sci. 42 (2): 101-108.

Zamiri, M. J. and Heidari, A. H. 2006. Reproductive characteristics of Rayini male goats of Kerman province in Iran. Animal Reproduction Science, 96: 176-185.

Zinat Mahal, Khandoker, M. A. M. Y. and Haque, M. N. 2013. Effect of nongenetic factors on productive traits of Black Bengal goats. Journal of Bangladesh Agricultural University. 11(1): 79-86.

\section{How to cite this article:}

Patel, D. K., C. F. Chaudhari, N. F. Chaudhari, L. C. Modi, V. B. Atara, P. P. Panchal and Amarjeet. 2020. Monthly Variations in Fresh Semen Parameters of Surti Buck in Rainy Season. Int.J.Curr.Microbiol.App.Sci. 9(12): 1398-1403. doi: https://doi.org/10.20546/ijcmas.2020.912.168 